Article

\title{
Kinetics of the Formation and Dissociation of Gas Hydrates from $\mathrm{CO}_{2}-\mathrm{CH}_{4}$ Mixtures
}

\author{
Kristine Horvat ${ }^{1}$, Prasad Kerkar ${ }^{1}$, Keith Jones ${ }^{1}$ and Devinder Mahajan ${ }^{1,2, *}$ \\ 1 Materials Science and Engineering Department, Stony Brook University, Stony Brook, New York, \\ NY 11794, USA; E-Mails: khorvat@ic.sunysb.edu (K.H.); kerkarpb@gmail.com (P.K.); \\ jones@bnl.gov (K.J.)
}

2 Sustainable Energy Technologies Department, Brookhaven National Laboratory, Upton, New York, NY 11973-5000, USA

* Author to whom correspondence should be addressed; E-Mail: dmahajan@bnl.gov;

Tel.: +1-631-632-1813; Fax: +1-631-632-8052.

Received: 6 February 2012; in revised form: 3 May 2012 / Accepted: 25 May 2012 /

Published: 6 July 2012

\begin{abstract}
Sequestration of carbon dioxide $\left(\mathrm{CO}_{2}\right)$ in the form of its hydrates in natural methane $\left(\mathrm{CH}_{4}\right)$ hydrate reservoirs, via $\mathrm{CO}_{2} / \mathrm{CH}_{4}$ exchange, is an attractive pathway that also yields valuable $\mathrm{CH}_{4}$ gas as product. In this paper, we describe a macroscale experiment to form $\mathrm{CO}_{2}$ and $\mathrm{CH}_{4}-\mathrm{CO}_{2}$ hydrates, under seafloor-mimic conditions, in a vessel fitted with glass windows that provides visualization of hydrates throughout formation and dissociation processes. Time resolved pressure and temperature data as well as images of hydrates are presented. Quantitative gas conversions with pure $\mathrm{CO}_{2}$, calculated from gas chromatographic measurements yielded values that range from $23-59 \%$ that correspond to the extent of formed hydrates. In $\mathrm{CH}_{4}$-rich $\mathrm{CH}_{4}-\mathrm{CO}_{2}$ mixed gas systems, $\mathrm{CH}_{4}$ hydrates were found to form preferentially.
\end{abstract}

Keywords: methane hydrate; carbon dioxide hydrate; mixed gas hydrate; carbon sequestration; sodium dodecyl sulfate

\section{Introduction}

Much attention has been paid to sequestration of $\mathrm{CO}_{2}$ in saline aquifers, coal beds, and abandoned petroleum reservoirs as a way to curb atmospheric greenhouse effects [1-5]. Specifically, there is 
interest in storing $\mathrm{CO}_{2}$ in gas hydrates on the ocean floor [6] as hydrates can provide a secondary storage method for $\mathrm{CO}_{2}$ in the ocean, thereby minimizing a chance for stored $\mathrm{CO}_{2}$ leakage [7].

The chemistry associated with $\mathrm{CO}_{2}$ hydrate formation is as follows: hydrates are inclusion compounds in which a hydrogen-bonded water cage confines a molecule of $\mathrm{CO}_{2}$. Hydrate cages are held together by weak van der Waals forces that reduce the free energy of the compound, making it stable at low temperatures and high pressures [8]. Sequestration of $\mathrm{CO}_{2}$ as a hydrate is, therefore, an attractive method.

Ohgaki et al. [9] devised the idea of simultaneously storing $\mathrm{CO}_{2}$ while extracting $\mathrm{CH}_{4}$ from deep ocean sediments. The idea is based on the premise that replacing $\mathrm{CH}_{4}$ gas with $\mathrm{CO}_{2}$ is a favorable process which will maintain seafloor stability during and after the $\mathrm{CH}_{4} / \mathrm{CO}_{2}$ exchange, thus minimizing disturbance to the natural environment. Two factors contribute to this hypothesis: (1) structurally, $\mathrm{CH}_{4}$ and $\mathrm{CO}_{2}$ gases are similar - both are classified as structure I (sI) hydrate, which consist of two pentagonal dodecahedra $\left(5^{12}\right)$ cages and six tetrakaidecahedra $\left(5^{12} 6^{2}\right)$ cages [8] and (2) hydrates of $\mathrm{CO}_{2}$ are more thermodynamically stable than $\mathrm{CH}_{4}$ at temperatures below $10^{\circ} \mathrm{C}[10]$. The phase diagram of $\mathrm{CO}_{2}$ and $\mathrm{CH}_{4}$ hydrates in Figure 1 shows the stability zones of both hydrates. As seen in Equations (1) and (2), no additional energy is needed to dissociate $\mathrm{CH}_{4}$ hydrates, since $\mathrm{CO}_{2}$ hydrate formation is exothermic and the heat of formation of $\mathrm{CO}_{2}$ hydrates is enough to dissociate $\mathrm{CH}_{4}$ hydrates, the latter releases free $\mathrm{CH}_{4}[6]$ :

$$
\begin{array}{ll}
\mathrm{CO}_{2}(\mathrm{~g})+\mathrm{nH}_{2} \mathrm{O} \rightarrow \mathrm{CO}_{2}\left(\mathrm{H}_{2} \mathrm{O}\right)_{\mathrm{n}} & \Delta \mathrm{H}_{\mathrm{f}}=-57.98 \mathrm{~kJ} / \mathrm{mol} \\
\mathrm{CH}_{4}\left(\mathrm{H}_{2} \mathrm{O}\right)_{\mathrm{n}} \rightarrow \mathrm{CH}_{4}(\mathrm{~g})+\mathrm{nH}_{2} \mathrm{O} \quad \Delta \mathrm{H}_{\mathrm{f}}=+54.49 \mathrm{~kJ} / \mathrm{mol}
\end{array}
$$

Figure 1. Hydrate stability curves for $\mathrm{CO}_{2}$ and $\mathrm{CH}_{4}$ gases.

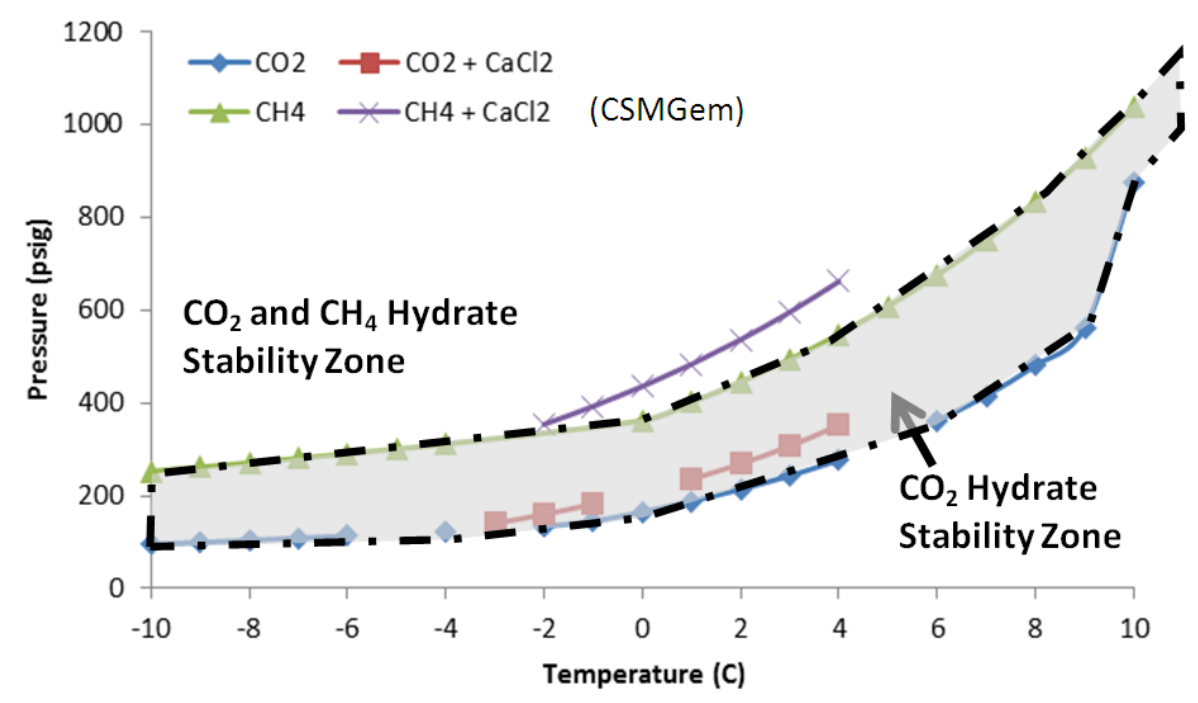

$\mathrm{CO}_{2}$ molecules prefer the larger $5^{12} 6^{2}$ cages while $\mathrm{CH}_{4}$ molecules fit easily in the smaller $5^{12}$ cages. This way, when $\mathrm{CO}_{2}$ is introduced into the $\mathrm{CH}_{4}$ hydrate zone, not all of the $\mathrm{CH}_{4}$ dissociates from its parent hydrate. Lee et al. [11] found that nearly $64 \%$ of methane gas could be extracted from methane hydrates of composition $\mathrm{CH}_{4} 6.05 \cdot \mathrm{H}_{2} \mathrm{O}$. In addition, the reverse reaction, $\mathrm{CH}_{4}$ gas replacing $\mathrm{CO}_{2}$ in hydrates, is very slow, so the potential for reformation of $\mathrm{CH}_{4}$ hydrates is low. $\mathrm{CO}_{2}$, in general, is thermodynamically a better guest molecule than $\mathrm{CH}_{4}[11]$. 
However, there are many issues that have not been addressed in previous studies. This study focused on the formation of gas hydrates on macroscale, from pure $\mathrm{CO}_{2}$ and mixed gases $\left(\mathrm{CO}_{2}-\mathrm{CH}_{4}\right.$ mixture) in the presence of sodium dodecyl sulfate (SDS), a commonly used hydrate former. Of particular focus was quantitative hydrate formation and decomposition data collection to establish hydrate formation kinetics, $\mathrm{P} / \mathrm{T}$ stability, and preferential hydrate formation in both pure and mixed gases. Since the pressure vessel in the experimental unit used was fitted with glass windows along the length, time resolved images also complemented this study. Such data would be a useful addition to the $\mathrm{CO}_{2} / \mathrm{CH}_{4}$ exchange data already known in literature.

\section{Materials and Methods}

Hydrate experiments on a macroscale were conducted in the Flexible Integrated Study of Hydrates (FISH) unit, shown in Figure 2. The unit was fitted with a series of gas input lines, interchangeable high-pressure cells, and a gas discharge/collection system. The gas input system consisted of $\mathrm{CO}_{2}$ and $\mathrm{CH}_{4}$ gas cylinders fitted with a series of valves, pressure regulators, and a flow meter/controller. The conditions inside the Jerguson cell $(\sim 198 \mathrm{~mL})$ that served as a high-pressure vessel (Figure 2), could mimic seafloor conditions by confining sediment-water mixture and allowing high-pressure gas (up to $14 \mathrm{MPa}$ ) to bubble up the column.

Figure 2. Set-up of the Flexible Integrated Study of Hydrates (FISH) Unit. The heart of the unit is a Jerguson cell fitted with glass windows that served as a high-pressure vessel to mimics seafloor conditions for the runs.

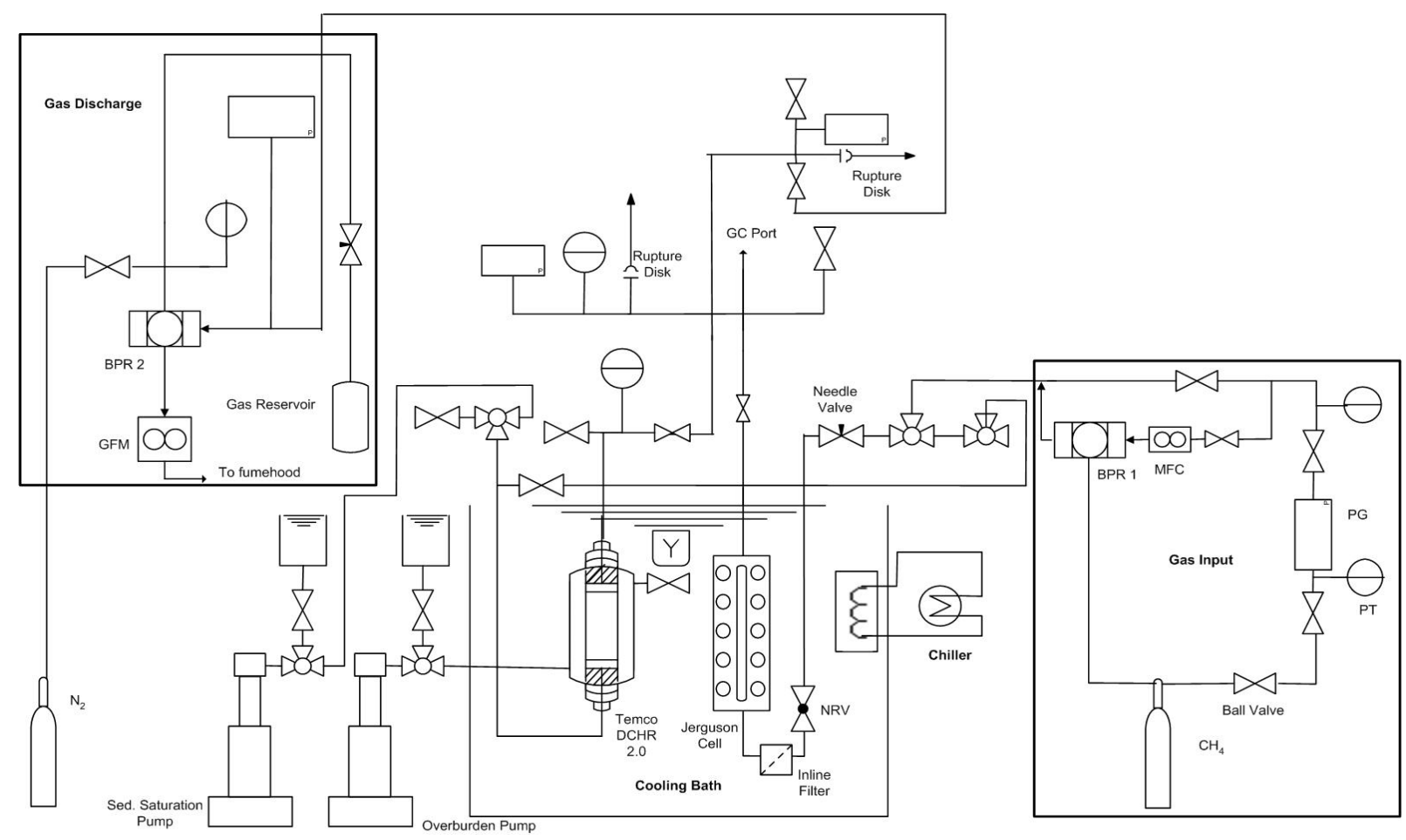

The Jerguson cell was fitted with glass windows along the entire length of the cell that allowed visual monitoring of hydrate formation and decomposition events through acquired images. The pressure transducer at the top of this vessel and several thermocouples located at the top and bottom of 
the cell monitored the temperatures of the gas and liquid phases, respectively through a LABView data acquisition system. This cell was kept in a water bath maintained at isothermal temperatures throughout the experiments.

In a typical experiment, a $75 \mathrm{~mL}$ aqueous solution of $300 \mathrm{ppm}$ SDS was added into the cell in the unit. Pure gas $\left(\mathrm{CO}_{2}\right)$ or gas mixture $\left(\mathrm{CH}_{4} / \mathrm{CO}_{2}\right)$ was slowly bubbled into the cell through the solution until a desired operating pressure was attained. The cell was then cooled to attain a temperature between -1 and $-2{ }^{\circ} \mathrm{C}$. Hydrate formation continued until the cell pressure asymptoted. At this point, the bath temperature was increased to temperatures above freezing to prevent ice formation. Multiple visual observations were taken throughout the hydrate formation event. In a few runs, the cell was recharged with gas to allow additional hydrate formation. To capture and measure absorbed gas in formed hydrates, the reaction was reversed by dissociation, induced by thermal stimulation of the cell to room temperature.

Gas samples $(\sim 0.5 \mathrm{~mL})$ of the free gas from the cell, after formation and during dissociation, were analyzed on a Gow Mac series 580 gas chromatograph (GC) fitted with a Supelco Carbonex $100045 / 60(1.5 \mathrm{~m} \times 0.32 \mathrm{~mm})$ packed column. The sample analysis procedure involved taking a $0.5 \mathrm{~mL}$ gas sample form the headspace of the cell and injecting in the GC. Gas compositions were calculated using pure $\mathrm{CH}_{4}$ and $\mathrm{CO}_{2}$ as reference gases.

\section{Results and Discussion}

A series of hydrate formation runs were performed to study the stability of $\mathrm{CO}_{2}$ hydrates in a water-SDS solution at $\sim-1{ }^{\circ} \mathrm{C}$. Table 1 lists experimental Pressure/Temperature (P/T) conditions, theoretical yields, and actual percent conversions achieved.

Table 1. Experimental Conditions and Results from Runs in the FISH unit. (Liquid volume: $75 \mathrm{~mL}$ of 300 ppm SDS Solution). * Recharge after Run 1.

\begin{tabular}{|c|c|c|c|c|c|c|c|}
\hline Run \# & Gas & $\begin{array}{l}\mathbf{T}_{\text {exp }} \\
\left({ }^{\circ} \mathbf{C}\right)\end{array}$ & $\begin{array}{c}\text { Charge } \\
\#\end{array}$ & $\begin{array}{c}\text { Initial } \\
\text { Pressure } \\
\text { (psig) }\end{array}$ & $\begin{array}{c}\text { Pressure } \\
\text { Drop }(\Delta) \\
(p s i) \\
\end{array}$ & $\begin{array}{c}\text { Measured } \\
\text { Conversion } \\
(\%) \\
\end{array}$ & $\begin{array}{c}\text { Theoretical } \\
\text { Conversion } \\
(\%)\end{array}$ \\
\hline \multirow{2}{*}{1} & \multirow{2}{*}{$\mathrm{CO}_{2}$} & \multirow{2}{*}{-1} & 1 & 425 & 132 & 30.0 & 63.6 \\
\hline & & & 2 & 503 & 170 & 32.8 & 69.0 \\
\hline 2 & $\mathrm{CO}_{2}$ & -1 & $*$ & 590 & 140 & 23.2 & 73.5 \\
\hline \multirow{2}{*}{3} & \multirow{2}{*}{$\mathrm{CO}_{2}$} & \multirow{2}{*}{-2} & 1 & 449 & 152 & 32.8 & 67.9 \\
\hline & & & 2 & 512 & 44 & 8.4 & 71.7 \\
\hline \multirow{2}{*}{4} & $\mathrm{CH}_{4}-\mathrm{CO}_{2}$ & \multirow{2}{*}{-1} & \multirow{2}{*}{1} & \multirow{2}{*}{992} & \multirow{2}{*}{427} & \multirow{2}{*}{42.4} & \multirow{2}{*}{77.6} \\
\hline & $(62 \%-38 \%)$ & & & & & & \\
\hline \multirow{2}{*}{5} & $\mathrm{CH}_{4}-\mathrm{CO}_{2}$ & \multirow{2}{*}{-1} & \multirow{2}{*}{1} & \multirow{2}{*}{1004} & \multirow{2}{*}{603} & \multirow{2}{*}{59.2} & \multirow{2}{*}{77.9} \\
\hline & $(62 \%-38 \%)$ & & & & & & \\
\hline
\end{tabular}


These high pressure and low temperature conditions resulted in $\mathrm{CO}_{2}$ hydrates that were observed from gas absorption and visual monitoring through the glass window on the cell. It is thermodynamically clear that gas hydrates formed as the system pressure decreased below the pressure that the system should have remained at for the given temperature conditions.

The volume ratio of gas/water was 1.67 in the cell. The gas/water ratio was maintained to keep experimental conditions in which water, not gas, was in excess. The steps leading to \% conversion data are as follows. The first gas charging in Run 1 led to a $30 \%$ conversion of $\mathrm{CO}_{2}$ into hydrates after about $67 \mathrm{~h}$ (Figure 3).

Figure 3. $\mathrm{P} / \mathrm{T}$ versus time data plot during gas charging and hydrate formation in Run 1. Cell volume: $198 \mathrm{~mL}$; Water: $75 \mathrm{~mL}$; SDS: 300 ppm; Bath $\mathrm{T}:+5{ }^{\circ} \mathrm{C}$; Actual cell T: $-1{ }^{\circ} \mathrm{C}$; Initial charging P: 425 psig (charge \#1); Charge \#2: 503 psig.

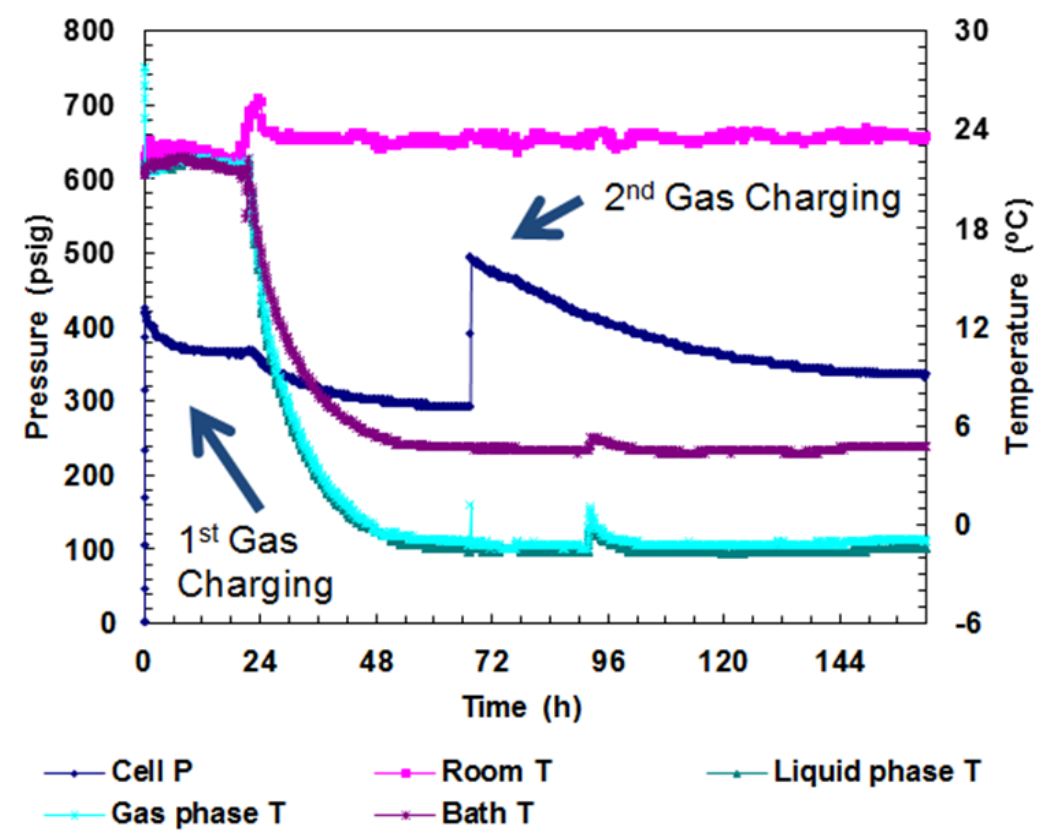

After charging, the initial cell pressure drop from 425 psig to 390 psig was attributed to gas cooling inside the cell. Any further pressure drop under isothermal conditions was attributed to hydrate formation. In the case of Run 1, a total pressure drop of 132 psig was observed over a period of $55 \mathrm{~h}$ at $-1{ }^{\circ} \mathrm{C}$. After this time period, the cell pressure remained constant over $15 \mathrm{~h}$. At this time after the first charge dropped to below $300 \mathrm{psig}$, the cell was repressurized to $503 \mathrm{psig}$ at $-1{ }^{\circ} \mathrm{C}$. The pressure again dropped, this time to about $344 \mathrm{psig}$, which remained constant for over $24 \mathrm{~h}$. This second charging resulted in a $33 \%$ conversion of $\mathrm{CO}_{2}$ into hydrates. The cooling was then discontinued and the entire cell was warmed to room temperature. Figure 4 is an image taken after $\mathrm{CO}_{2}$ hydrates were viewed at the bottom aqueous phase of the cell at around $96 \mathrm{~h}$ into the experiment. Figure 5 is a close up of formation cell $\mathrm{P} / \mathrm{T}$ against time. The images shown in Figure 6 were taken during $\mathrm{CO}_{2}$ hydrate formation and their thermally induced dissociation. During dissociation, gas bubbles were seen to form uniformly throughout the viewing area in ice pockets as hydrates reverted back to water and $\mathrm{CO}_{2}$ was released. 
Figure 4. $\mathrm{CO}_{2}$ Hydrates formed during Run 1. The run conditions are shown in Figure 3. The image on the right is a close up of the hydrates shown in the reactor on the left.

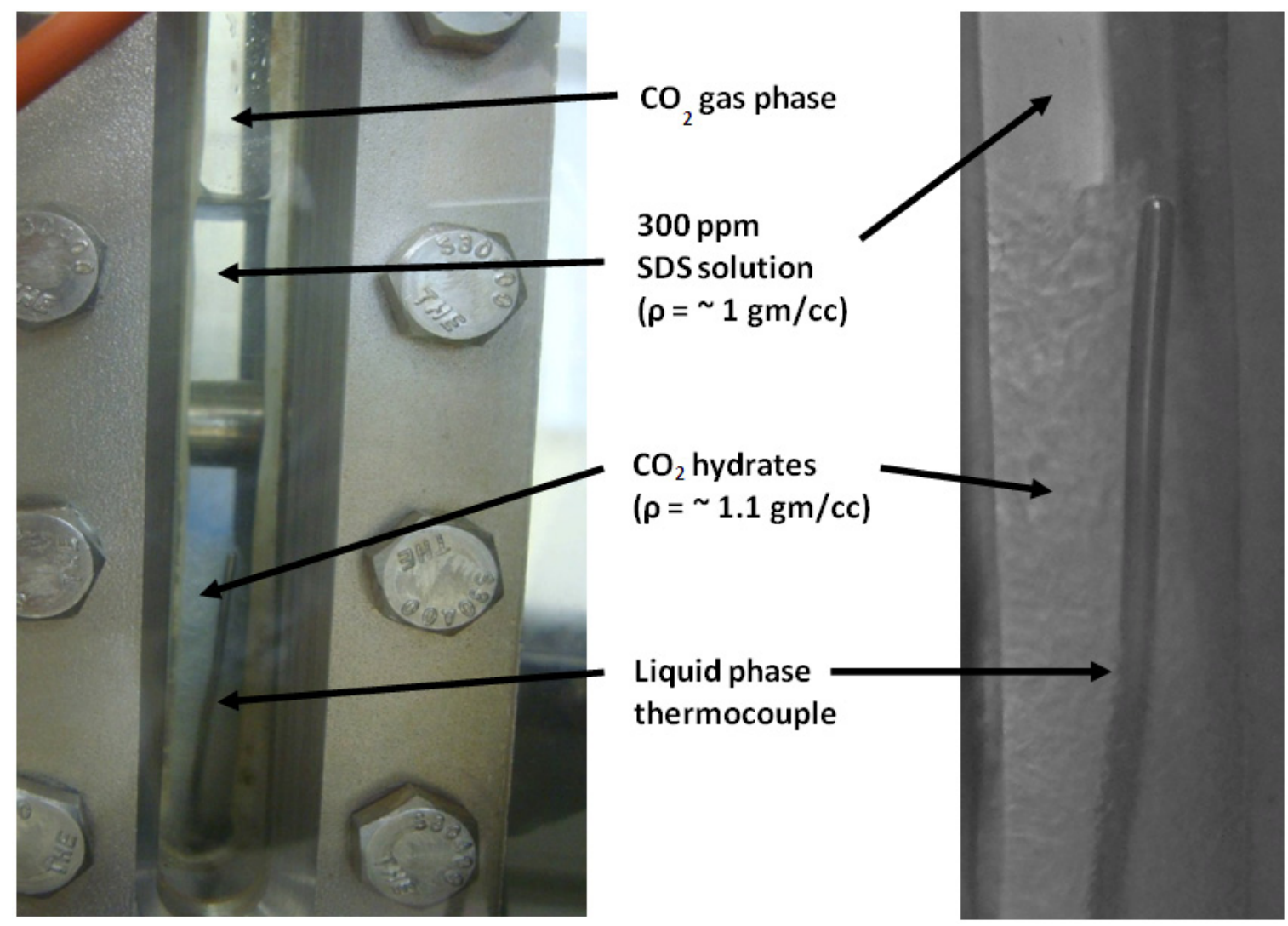

Figure 5. $\mathrm{P} / \mathrm{T}$ versus time data plots during dissociation by thermal stimulation for Run 1 . The run conditions are shown in Figure 3.

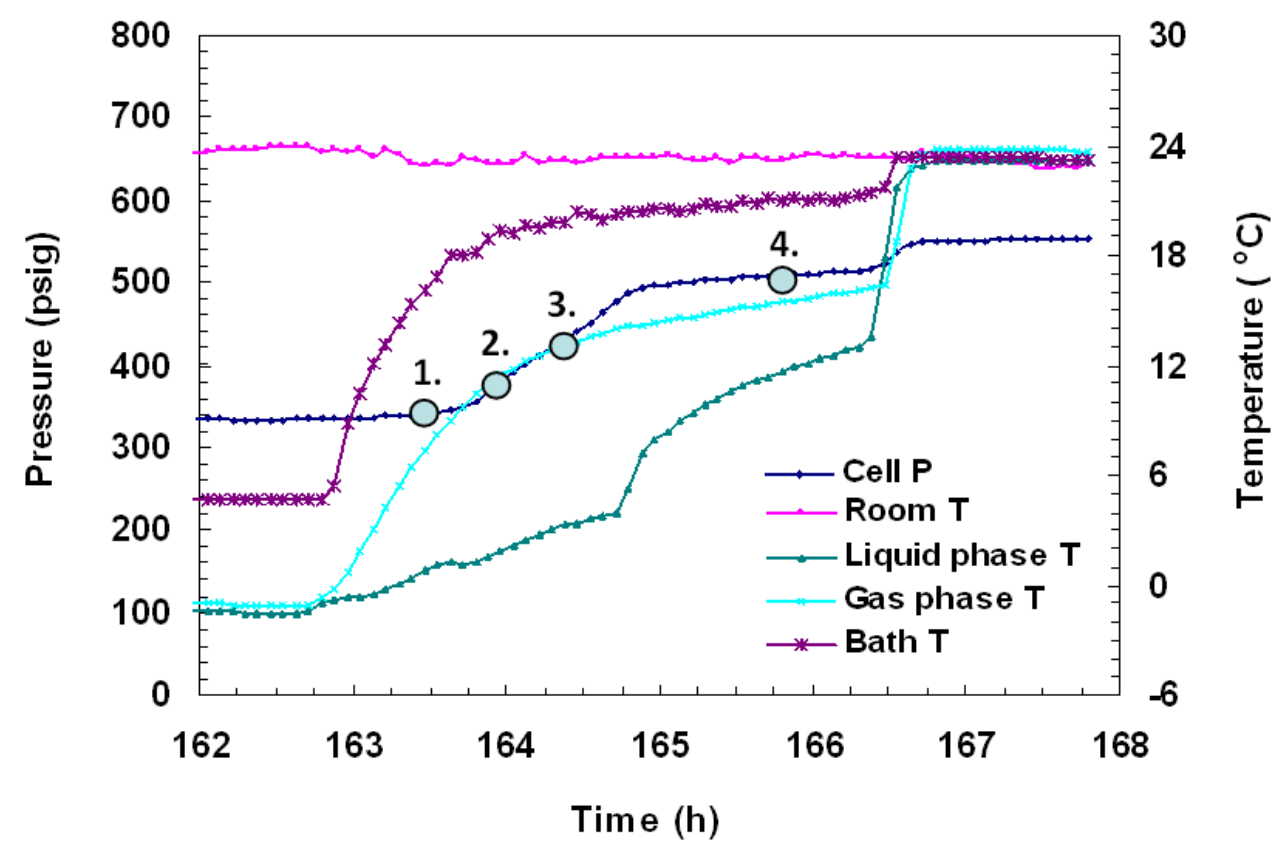


Figure 6. Time resolved visual observations of the $\mathrm{CO}_{2}$ hydrate phase during Run 1 at (a) $339 \mathrm{psig}, 5.46{ }^{\circ} \mathrm{C}$; (b) $369 \mathrm{psig}, 1.62{ }^{\circ} \mathrm{C}$; (c) $428 \mathrm{psig}, 12.98{ }^{\circ} \mathrm{C}$; (d) $508 \mathrm{psig}, 15.28{ }^{\circ} \mathrm{C}$. These letters correspond to the numbered $\mathrm{P} / \mathrm{T}$ conditions shown in the dissociation plot of Figure 5 where point 1 in Figure 5 represents (a) shown below. $\mathrm{CO}_{2}$ hydrates (density $1.1 \mathrm{~g} / \mathrm{cc}$ ) were observed to have an ice-like appearance in the aqueous phase at temperatures above the freezing point of a water-SDS solution.

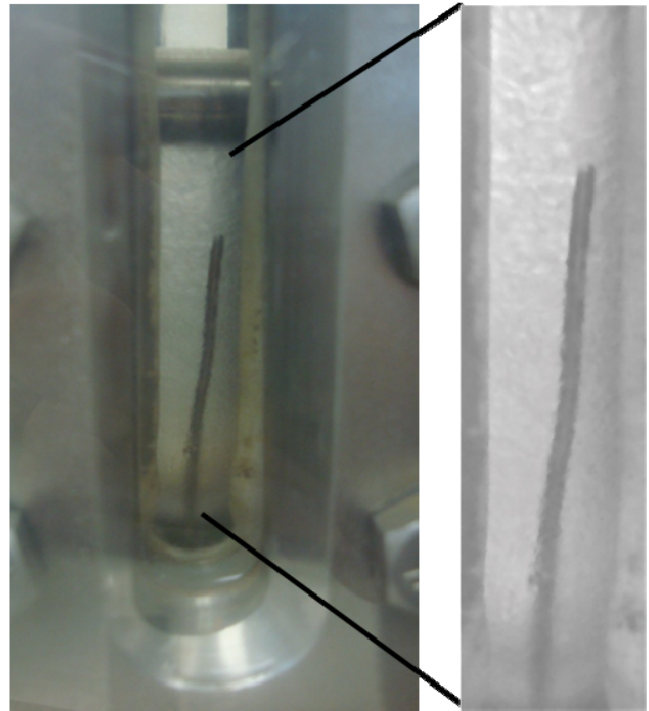

(a)

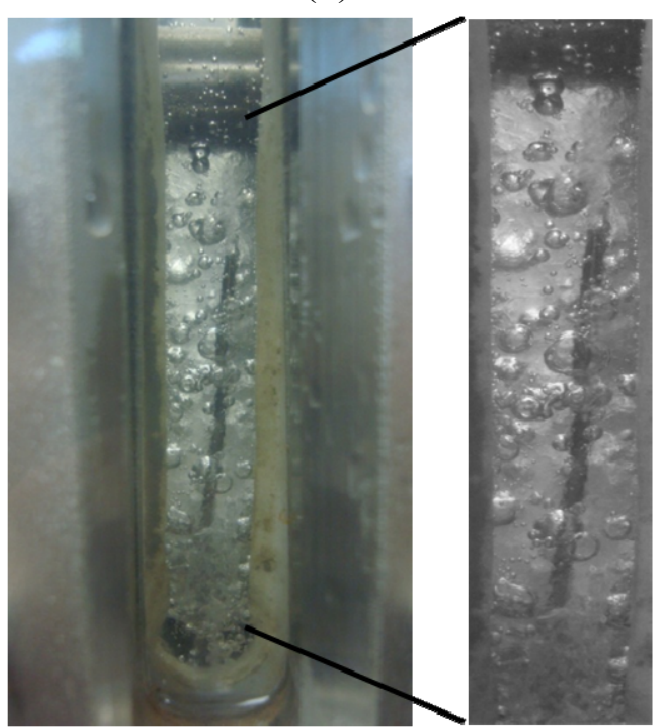

(c)

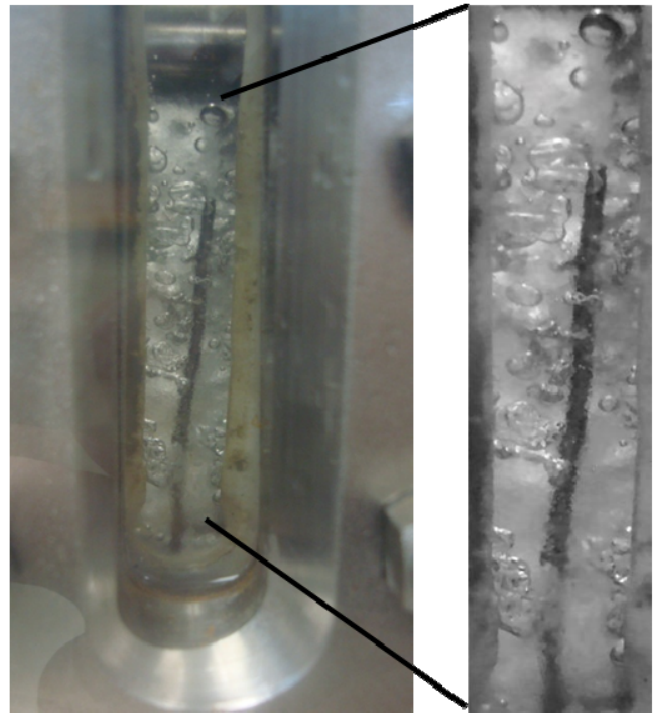

(b)

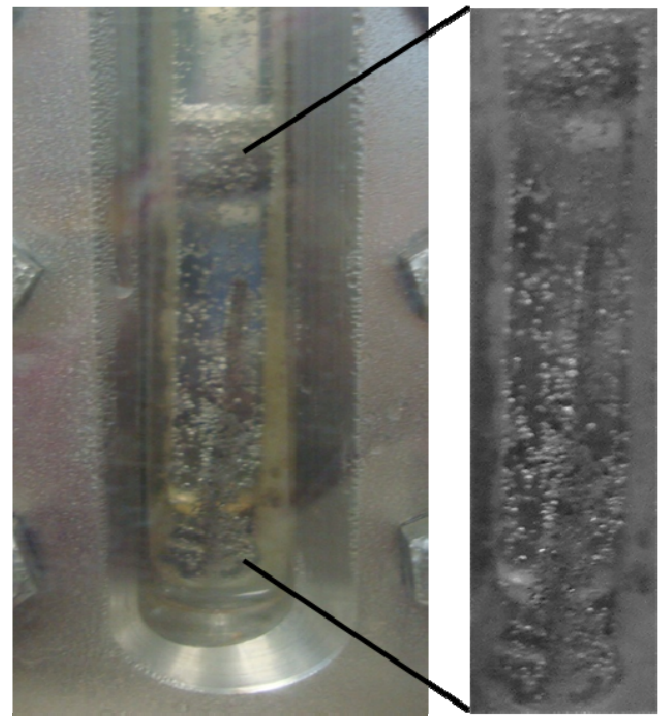

(d)

Run 2 was performed using the same $\mathrm{CO}_{2}$ gas and 300 ppm SDS solution that was used in Run 1. Once the cell warmed up to room temperature and all $\mathrm{CO}_{2}$ hydrates formed during Run 1 had dissociated (no more gas evolution was observed), 40 psi of additional $\mathrm{CO}_{2}$ gas was added to the system to thoroughly mix the gas/liquid phases inside the cell. Over nine days, the initial cell pressure of 590 psig slowly dropped to 450 psig while the cell temperature was held at $-1{ }^{\circ} \mathrm{C}$. At this time, the cell was warmed to increase the temperature to $+1{ }^{\circ} \mathrm{C}$ (to melt any ice that had formed), leaving only $\mathrm{CO}_{2}$ hydrates in the cell. A total pressure drop of 140 psig resulted in a hydrate conversion of $23 \%$. Hydrates were observed in the cell, similar to those shown in Figures 4 and 6 for Run 1. Figure 7(a) shows cell the $\mathrm{P} / \mathrm{T}$ against time data for the entire Run 2 . 
After the hydrate formation event in Run 2 was complete, the cell was depressurized. The SDS solution used in the previous run was left in the cell and used again in Run 3, and the cell was pressurized to 449 psig with fresh $\mathrm{CO}_{2}$. After charging, the initial cell pressure drop from 449 psig to 297 psig was attributed to gas cooling inside the cell and hydrate formation. The first gas charging in Run 3 led to a $33 \%$ conversion of $\mathrm{CO}_{2}$ into hydrates as shown in Figure 7(b). A total pressure drop of 152 psig was observed over a period of $42 \mathrm{~h}$ at $-2{ }^{\circ} \mathrm{C}$. After this time period, the cell pressure remained constant over $30 \mathrm{~h}$. At this time, the cell was repressurized to 512 psig at $-2{ }^{\circ} \mathrm{C}$. The initial pressure drop was due to cell cooling but once isothermal conditions were attained, the pressure drop was attributed to hydrate formation. After a total of $144 \mathrm{~h}$, the temperature of the cell was raised to $+2{ }^{\circ} \mathrm{C}$ to ensure hydrate rather than ice formation. When the temperature was raised above freezing, pressure continued to drop, indicating further hydrate formation until the cell warmed to room temperature. This second charging event only resulted in a hydrate conversion of $8 \%$. Hydrates were visually observed in the cell, similar to those observed during Run1 (Figures 4 and 6).

Figure 7. Cell P/T versus Time data plots for: (a) Run 2 at $-1{ }^{\circ} \mathrm{C}$ and 590 psig; (b) Run 3 at $-2{ }^{\circ} \mathrm{C}$ and 512 psig.

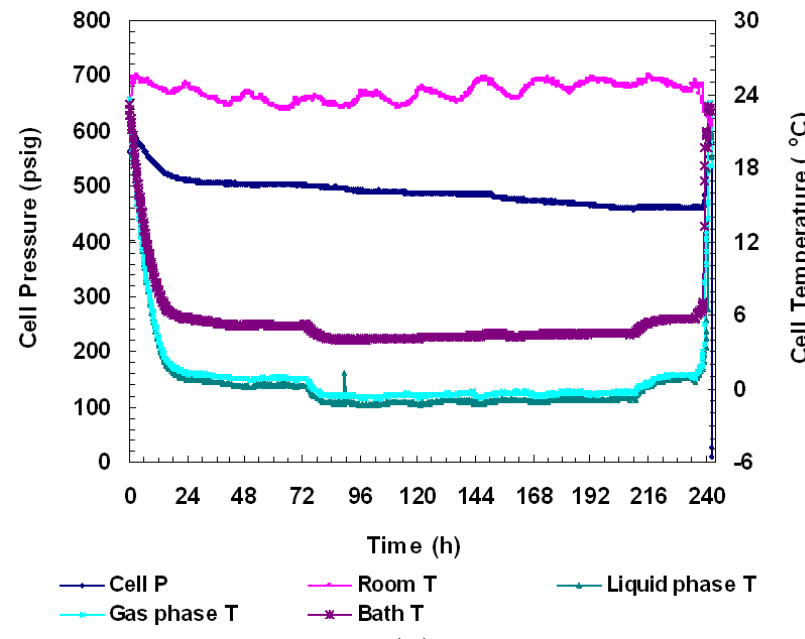

(a)

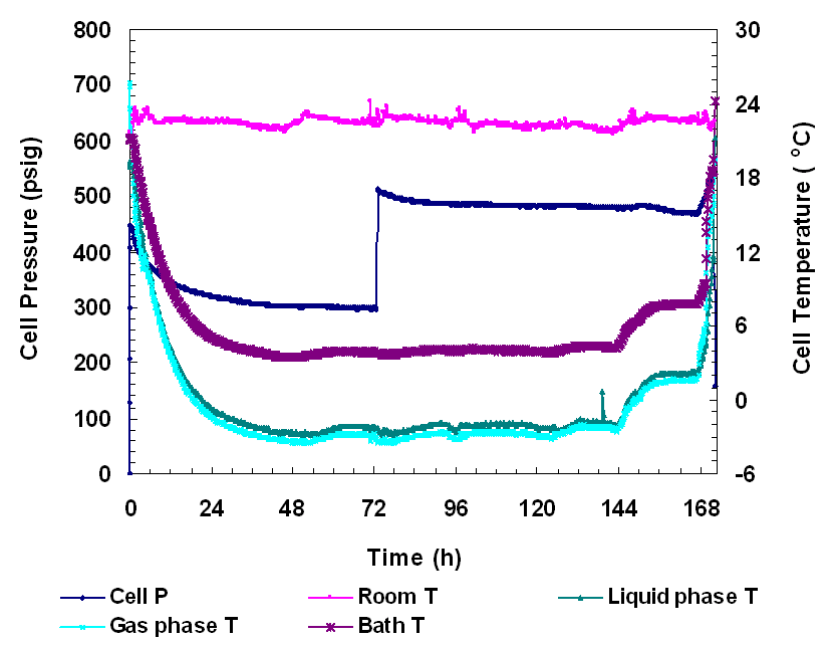

(b)

Recharging runs 1 and 3 with $\mathrm{CO}_{2}$ showed an additional $32 \%$ and $8 \%$ gas conversion into hydrates respectively. This is expected because these were water-excess systems. Initially, 0.16 to 0.23 moles of $\mathrm{CO}_{2}$ were charged into the cell while 4.17 moles of solution were present. The ratio for our system of gas to solution is far below the $1 / 6.05$ mole ratio of $\mathrm{CO}_{2}$ to water needed for full cage occupancy for $\mathrm{CO}_{2}$ hydrates. The higher charging pressure was found to result in a higher percentage conversion during charge \#2 in Run 1 though a low hydrate formation during charge \#2 in Run 3 may be due to poor gas-liquid mass transfer. Hydrates are usually found to nucleate at the gas-liquid interface [12], but there is a potential that hydrates nucleated at the gas-liquid interface and then accumulated in the aqueous phase due to density differences between the aqueous phase $(1 \mathrm{~g} / \mathrm{cc})$ and the $\mathrm{CO}_{2}$ hydrates $(1.1 \mathrm{~g} / \mathrm{cc})$. Hydrates have also been hypothesized to nucleate in the aqueous phase by "local structuring" or "labile clustering" [13].

Of the runs with $\mathrm{CO}_{2}$ (runs 1-3), Run 2 achieved the least conversion $(\sim 23 \%)$ of $\mathrm{CO}_{2}$ into hydrates as the solution and $\mathrm{CO}_{2}$ gas previously used in Run 1 was reused to form hydrates. SDS used as a 
promoter in these runs has a tendency to precipitate out of aqueous solutions. This was confirmed in a previous study by Lee et al. [14] in which a high concentration of SDS under higher pressures was found to precipitate out earlier than that at lower concentrations. The least conversion observed in Run 2 may be due to the precipitation of SDS after a cumulative 17 days for runs 1 and 2. Also, in this run, SDS precipitation seems to have inhibited the hydrate memory effect. In addition, Wu and Zhang [15] have shown that if the hydrate depleted solution reaches temperatures above $25^{\circ} \mathrm{C}$, the memory effect will not occur. During dissociation, it is possible that the temperature of the cell reached $25^{\circ} \mathrm{C}$.

After successfully forming $\mathrm{CO}_{2}$ hydrates, runs were conducted to form hydrates from a $\mathrm{CH}_{4}-\mathrm{CO}_{2}$ mixed gas system. In Run 4, a fresh 300 ppm SDS solution was injected into the cell. The pressure was increased to 380 psig with $\mathrm{CO}_{2}$ gas, followed by 1000 psig with $\mathrm{CH}_{4}$ gas, thus forming a mixed gas system. Hydrates were observed in about 2 days after cooling had begun, so the initial cell pressure drop from 992 psig to 810 psig was attributed to gas cooling inside the cell at $-1{ }^{\circ} \mathrm{C}$. Any further pressure drop under isothermal conditions was attributed to hydrate formation. Upon initial formation, the cell temperature was increased to $+2{ }^{\circ} \mathrm{C}$ to thaw the ice phase and confirm hydrate stability and distinguish these from the ice phase. The cell was allowed to equilibrate and pressure remained constant around 750 psig for subsequent 4 days, after which a second drop in pressure was recorded, indicating further hydrate formation. This drop can be clearly seen in the $\mathrm{P} / \mathrm{T}$ versus time plot in Figure 8. After about $3 \mathrm{~h}$ of formation, the pressure remained constant for next $24 \mathrm{~h}$ at 565 psig, following which the cell was warmed to room temperature. A simple recorded pressure difference and change in the number of moles of gas present in the cell at the end of formation were calculated to show that $42 \%$ of the initial gas converted into hydrates, though $\mathrm{CO}_{2}$ and $\mathrm{CH}_{4}$ were indistinguishable.

Figure 8. A plot of $\mathrm{P} / \mathrm{T}$ versus time during charging and hydrate formation in Run 4. Hydrate formation was achieved from a $\mathrm{CH}_{4}-\mathrm{CO}_{2}$ mixture. The embedded pink dots represent gas compositions measured by analyzing gas samples at corresponding times.

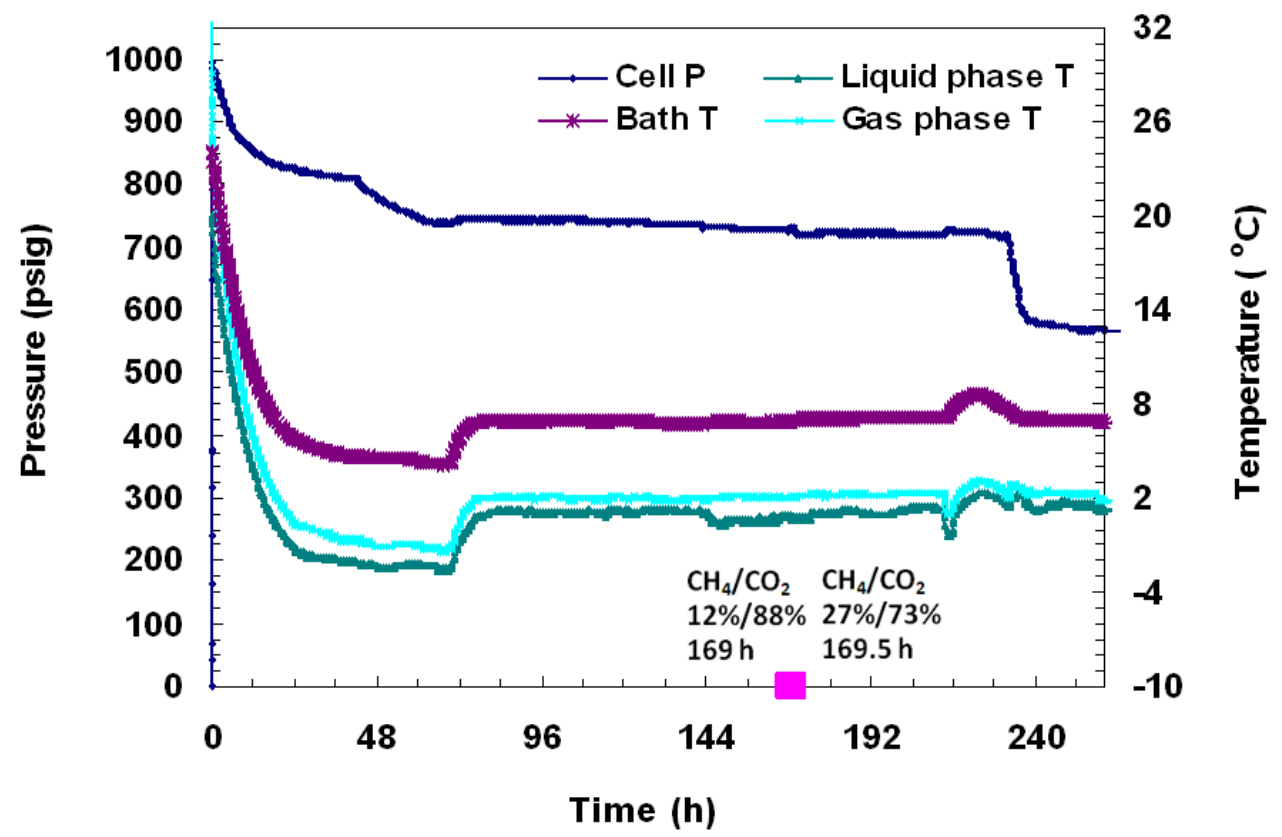


To discern the identity of hydrates, several gas samples $(0.5 \mathrm{~mL})$ were taken from the vessel and analyzed during formation and dissociation. The gas chromatographic (GC) data as \%volume change from initial and final gas values for each gas are shown in Figures 8 and 9. In Figure 8, it was found that at $169 \mathrm{~h}$ into the experiment when cell pressure was 748 psig and cell temperature was $+1{ }^{\circ} \mathrm{C}$, the gas phase of the cell consisted of $12 \% \mathrm{CH}_{4}$ and $88 \% \mathrm{CO}_{2}$. Subsequently, 30 minutes later, under the same $\mathrm{P} / \mathrm{T}$ conditions, another gas sample was taken and was found to be made up of $27 \% \mathrm{CH}_{4}$ and $73 \% \mathrm{CO}_{2}$. This indicates that initially, $\mathrm{CH}_{4}$ hydrates form, but as formation continues in the cell, more $\mathrm{CO}_{2}$ gas replaces $\mathrm{CH}_{4}$ in hydrates. Following the second pressure drop, three more GC gas samples were taken in Figure 9. The first gas sample, taken $284.5 \mathrm{~h}$ into the experiment at 568 psig and $+1.4{ }^{\circ} \mathrm{C}$, showed the gas composition as $66 \% \mathrm{CH}_{4} / 34 \% \mathrm{CO}_{2}$. One hour later, a sample taken at 567 psig and $+1.3{ }^{\circ} \mathrm{C}$ showed the gas composition as $63 \% \mathrm{CH}_{4} / 37 \% \mathrm{CO}_{2}$. The last gas sample, taken $1.5 \mathrm{~h}$ after thermal stimulation had begun at $638 \mathrm{psig}$ and $+1{ }^{\circ} \mathrm{C}$, showed gas as $68 \% \mathrm{CH}_{4} / 32 \% \mathrm{CO}_{2}$. Similar concentrations of $\mathrm{CH}_{4}$ and $\mathrm{CO}_{2}$ before and after formation were measured with $\mathrm{GC}$ analysis, which confirm similar relative \% conversions for both gases. Embedded in Figure 10 are images taken of the gas hydrates that formed in the vessel over time. The numbered points in Figure 9 represent the conditions for the lettered images in Figure 10 where point 1 in Figure 9 corresponds to image (a) of Figure 10.

Figure 9. $\mathrm{P} / \mathrm{T}$ against time during dissociation by thermal stimulation in Run 4. Hydrate formation was achieved from a $\mathrm{CH}_{4}-\mathrm{CO}_{2}$ mixture. The embedded pink dots represent gas compositions measured from gas samples analyzed in a Gow-Mac 580 series gas chromatograph.

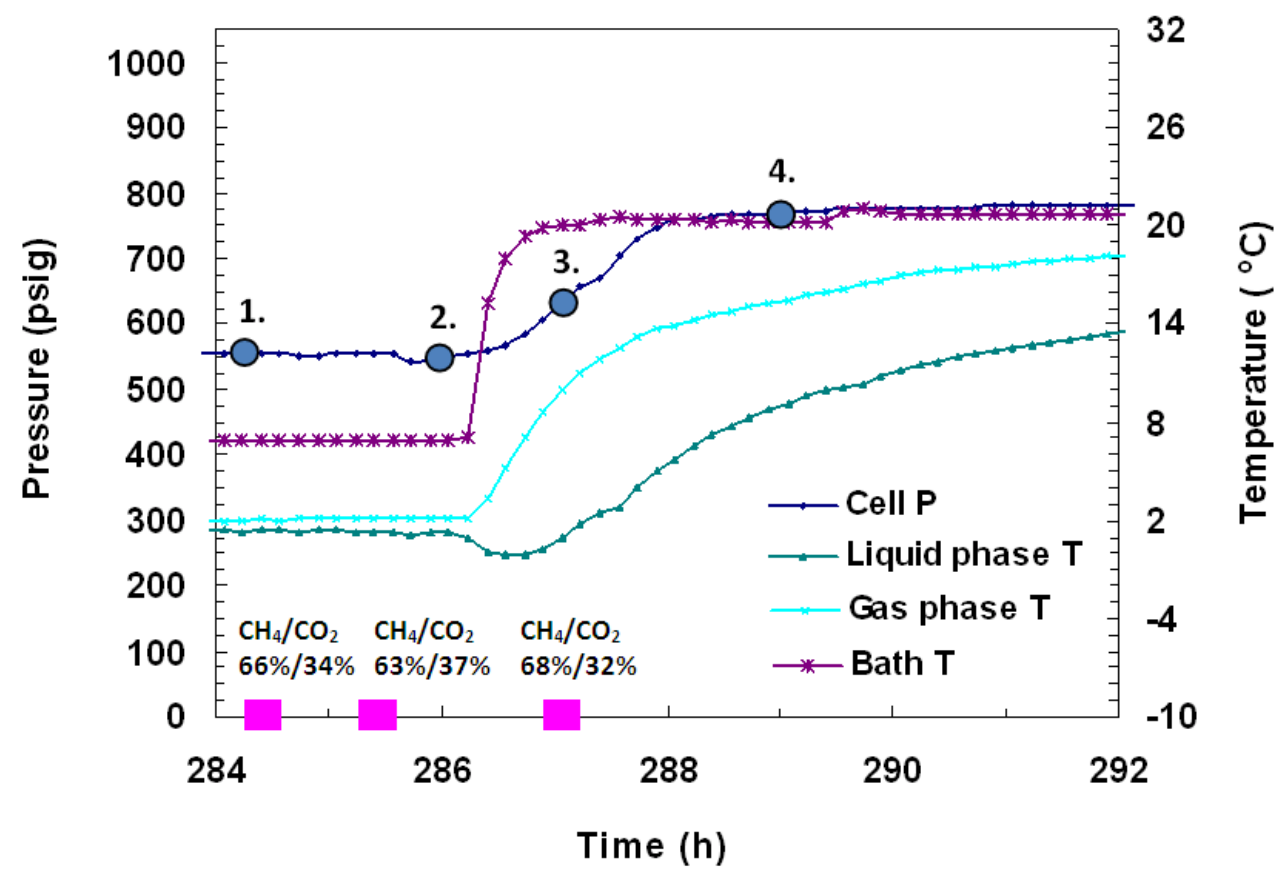


Figure 10. Time-resolved observations of the $\mathrm{CH}_{4}-\mathrm{CO}_{2}$ hydrate formation at the end of formation and during dissociation in Run 4 at (a) $574 \mathrm{psig}, 1.38{ }^{\circ} \mathrm{C}$; (b) $559 \mathrm{psig}, 1.34{ }^{\circ} \mathrm{C}$; (c) $629 \mathrm{psig}, 0.77{ }^{\circ} \mathrm{C}$; (d) $770 \mathrm{psig}, 8.92{ }^{\circ} \mathrm{C}$. These $\mathrm{P} / \mathrm{T}$ conditions correspond to the numbers shown in the dissociation plot of Figure 9 where point 1 in Figure 9 represents (a) shown below.

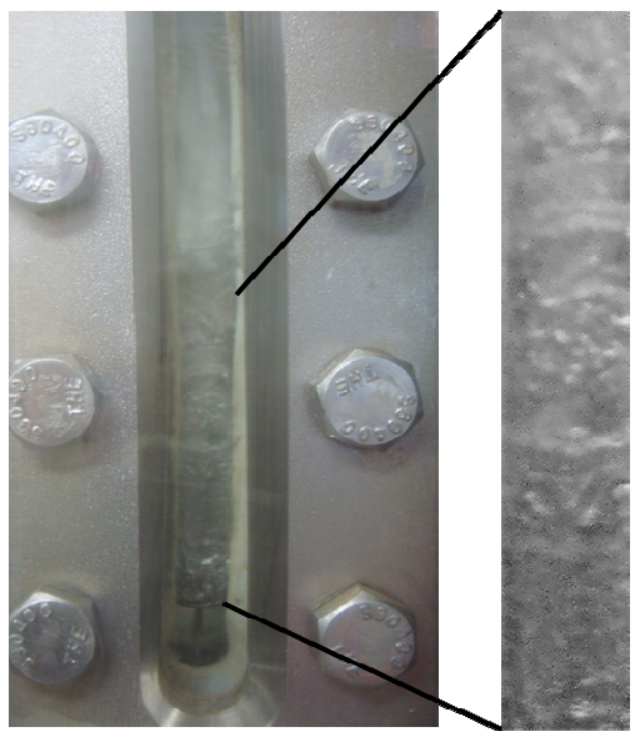

(a)

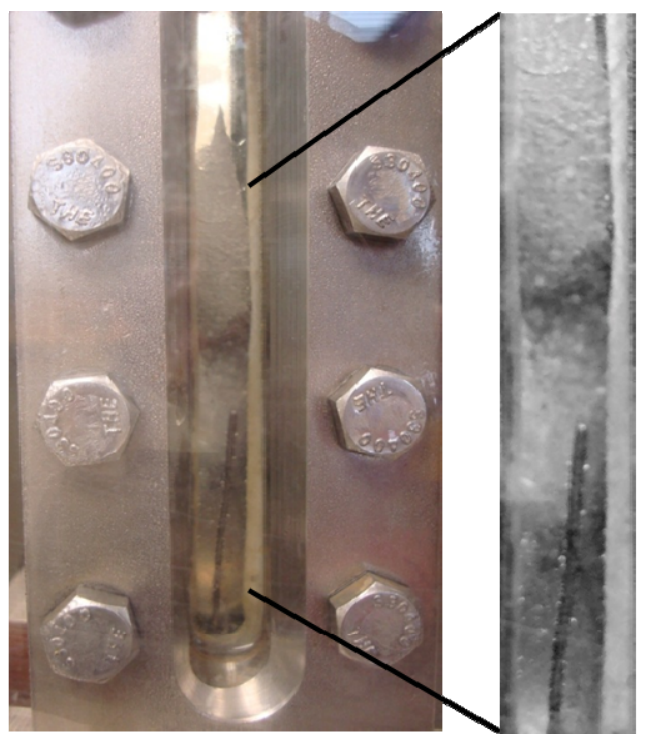

(c)

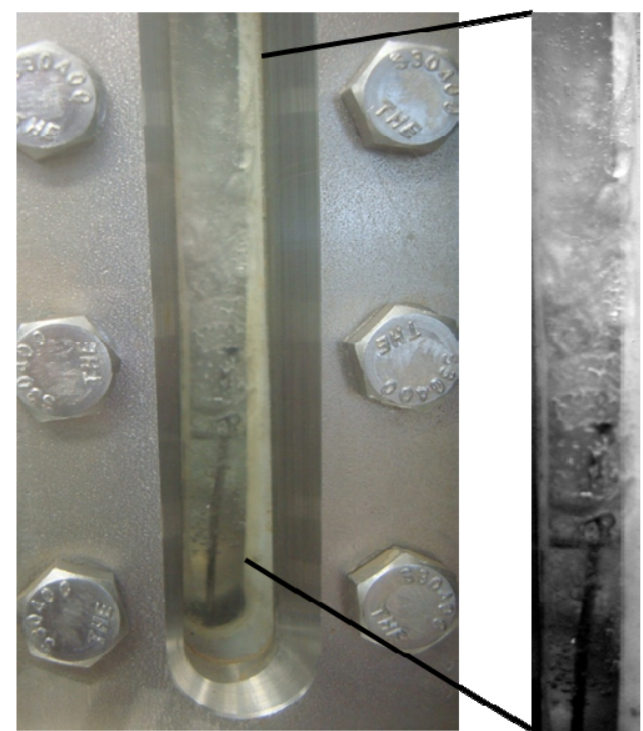

(b)

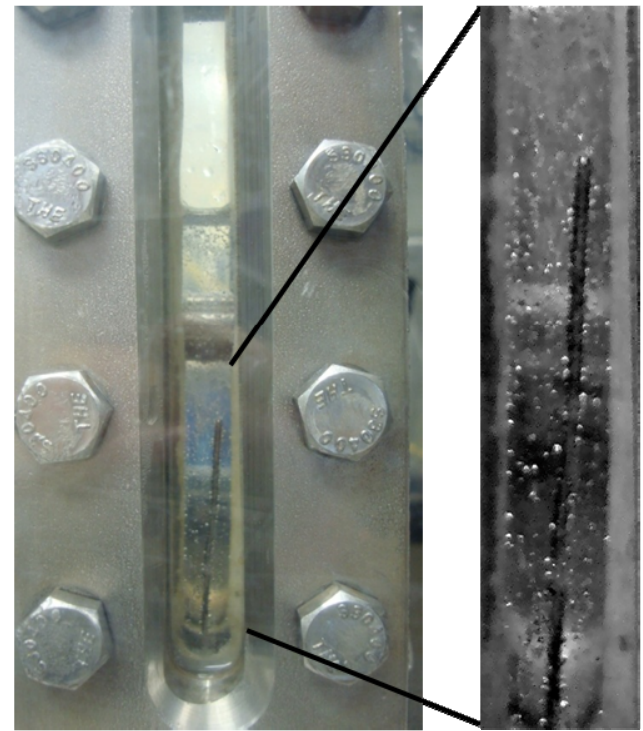

(d)

Run 5 was performed using the same procedure as described for Run 4 . In this case, the cell was pressurized to 380 psig with $\mathrm{CO}_{2}$ gas, followed by 1000 psig $\mathrm{CH}_{4}$ gas. Hydrates formed a day after cell cooling began. As shown in Figure 11, a pressure drop from 1004 psig to 880 psig due to cooling to $-1{ }^{\circ} \mathrm{C}$ was observed over the first $24 \mathrm{~h}$, followed by an abrupt pressure drop to 475 psig which was attributed to hydrate formation. A pressure of 410 psig was maintained for two days, after which the cell temperature was increased to $+2{ }^{\circ} \mathrm{C}$ to confirm the presence of the hydrate phase. Once the cell was warmed above freezing, pressure remained stable at 565 psig for $24 \mathrm{~h}$ until the run ended. An overall gas conversion of $59 \%$ into hydrates was achieved. 
Figure 11. (a) A plot of $\mathrm{P} / \mathrm{T}$ versus time during charging, formation, and dissociation from a $\mathrm{CH}_{4}-\mathrm{CO}_{2}$ mixture in Run 5; (b) A close-up view of hydrate dissociation by thermal stimulation. The embedded pink dots represent calculated gas compositions from gas chromatographic data.

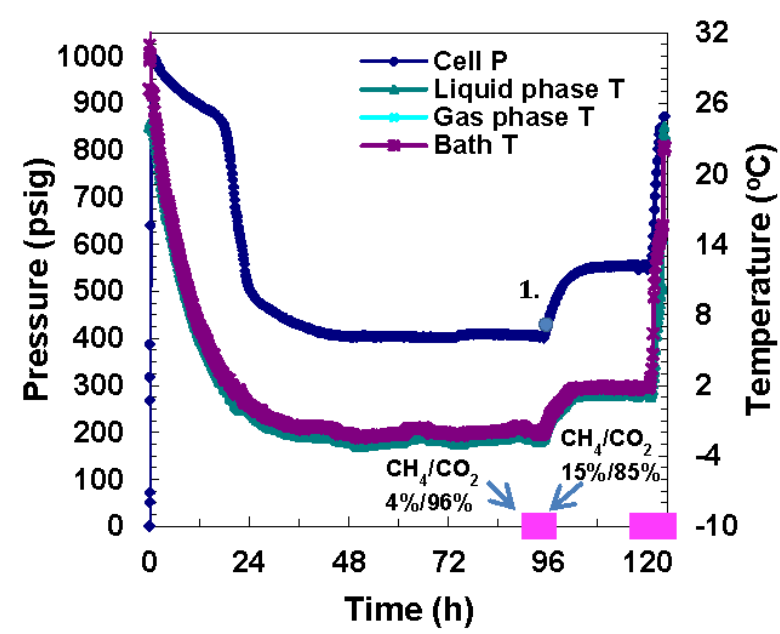

(a)

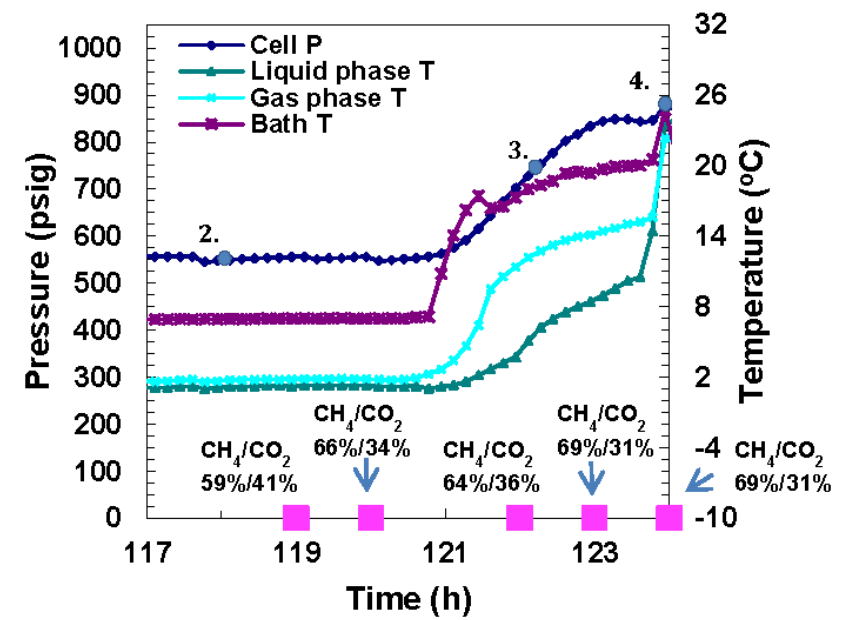

(b)

As described for the previous run, several gas samples were analyzed during formation and dissociation to calculate individual \% gas $\left(\mathrm{CO}_{2}\right.$ or $\left.\mathrm{CH}_{4}\right)$ that converted to hydrates. Figure 11 shows $\mathrm{P} / \mathrm{T}$ versus time plots and Figure 12 shows images of gas hydrate formation over time for Run 5, a mixed gas system. In Figure 11a, a gas sample was taken $94 \mathrm{~h}$ after the experiment had begun at 417 psig and $-2.5{ }^{\circ} \mathrm{C}$ and the gas composition was measured to be $4 \% \mathrm{CH}_{4} / 96 \% \mathrm{CO}_{2}$. Two hours later, at 406 psig and $-2.7{ }^{\circ} \mathrm{C}$, the gas composition was $15 \% \mathrm{CH}_{4} / 85 \% \mathrm{CO}_{2}$. Similarly in $\mathrm{Run} 4, \mathrm{CH}_{4}$ hydrates were seen to form in the earlier stages of formation, and as time went by, more $\mathrm{CO}_{2}$ hydrates formed. At this point, the cell temperature was raised to above freezing to ensure that the ice phase was not present in the cell. Five GC samples were taken prior to and during dissociation as shown in Figure $11 \mathrm{~b}$, which is a close up of day five of the experiment. The gas compositions under P: 566 psig and $\mathrm{T}:+1.3{ }^{\circ} \mathrm{C}$, at various time intervals were as follows: (1) Sample \#1, Time: $119 \mathrm{~h}$ : 59\% $\mathrm{CH}_{4} / 41 \% \mathrm{CO}_{2}$; (2) Sample \#2: Time: $120 \mathrm{~h}: 66 \% \mathrm{CH}_{4} / 34 \% \mathrm{CO}_{2}$. At this point, thermal stimulation was begun to bring about dissociation of formed hydrates. At $122 \mathrm{~h}$, the temperature was $2.4{ }^{\circ} \mathrm{C}$, the pressure increased to 644 psig and the gas analysis was: $64 \% \mathrm{CH}_{4} / 36 \% \mathrm{CO}_{2}$. At $123 \mathrm{~h}$, the pressure was 811 psig at $+7.7{ }^{\circ} \mathrm{C}$ and the corresponding gas analysis was: $69 \% \mathrm{CH}_{4} / 31 \% \mathrm{CO}_{2}$. At $124 \mathrm{~h}$, the pressure had increased to $860 \mathrm{psig}$ as the temperature increased to $+10.2{ }^{\circ} \mathrm{C}$ but the gas analysis was unchanged. The numbered points in Figure $11 \mathrm{a}$ and $11 \mathrm{~b}$ represent $\mathrm{P} / \mathrm{T}$ conditions in the cell when the lettered images in Figure 12 were taken where point 1 in Figure 11 corresponds to image (a) of Figure 12.

The hydrate formation runs with $62 \% \mathrm{CH}_{4} / 38 \% \mathrm{CO}_{2}$ gas mixtures resulted in gas conversions as high as $42 \%$ and $59 \%$. Hydrates from the $\mathrm{CH}_{4}-\mathrm{CO}_{2}$ mixture were found to grow uniformly throughout the cell as a massive structure. A solid structure in the form of hydrates was visually observed on the entire the viewing glass $(1 / 2$ in. $\times 12$ in.). Dissociation was also observed randomly throughout the hydrate phase. Both $\mathrm{CO}_{2}$ hydrates and $\mathrm{CH}_{4}$ hydrates were indistinguishable in terms of morphology to the naked eye, so it is unknown if $\mathrm{CO}_{2}$ and $\mathrm{CH}_{4}$ hydrates or mixed gas hydrates formed. 
It is apparent from the completed runs in the FISH unit that facile formation of both $\mathrm{CO}_{2}$ and $\mathrm{CH}_{4}$ hydrates was observed, under the $\mathrm{P} / \mathrm{T}$ conditions used. It was found that, especially in the early stages of hydrate formation, a majority of the gas that was stored in hydrates was $\mathrm{CH}_{4}$. Seo et al. (2001) [16] observed that at lower pressures, $\mathrm{CO}_{2}$ preferentially forms hydrates. Uchida et al. (2005) [17] formed $\mathrm{CH}_{4}-\mathrm{CO}_{2}$ hydrates and found that when the gas phase consisted predominantly of $\mathrm{CO}_{2}, \mathrm{CH}_{4}$ preferentially forms hydrates in the early stages of hydrate formation. The observed data are consistent with these observations though merits further investigation to understand the implication in natural $\mathrm{CH}_{4}$ hydrate reservoirs.

Figure 12. Time resolved visual observations of the $\mathrm{CH}_{4}-\mathrm{CO}_{2}$ hydrate phase at the end of formation and during dissociation for Run 5 at: (a) 460 psig, $-1.05{ }^{\circ} \mathrm{C}$; (b) $564 \mathrm{psig}$, $1.24{ }^{\circ} \mathrm{C}$; (c) $635 \mathrm{psig}, 2.44{ }^{\circ} \mathrm{C}$; (d) $848 \mathrm{psig}, 10.25{ }^{\circ} \mathrm{C}$. These $\mathrm{P} / \mathrm{T}$ conditions correspond to the numbers shown in the dissociation plot of Figure 11 where point 1 in Figure 11 represents (a) shown below.

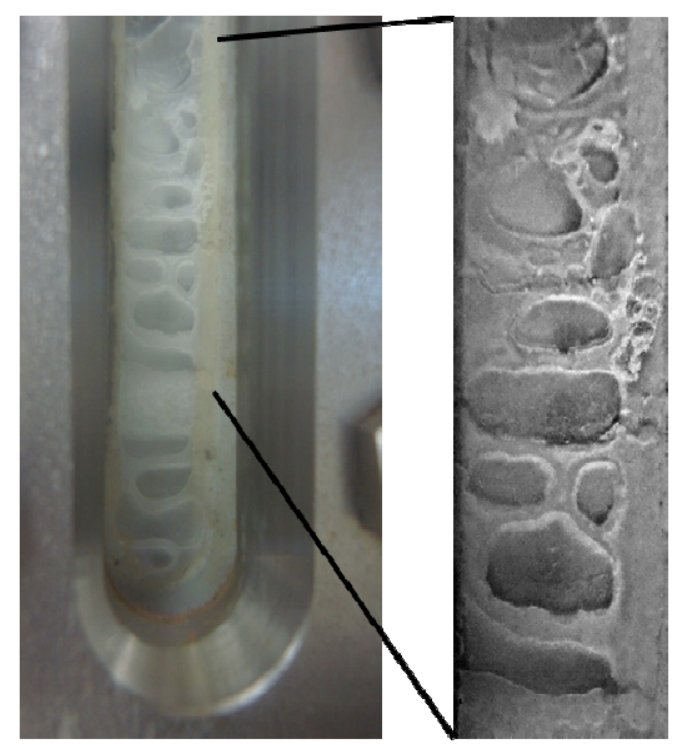

(a)

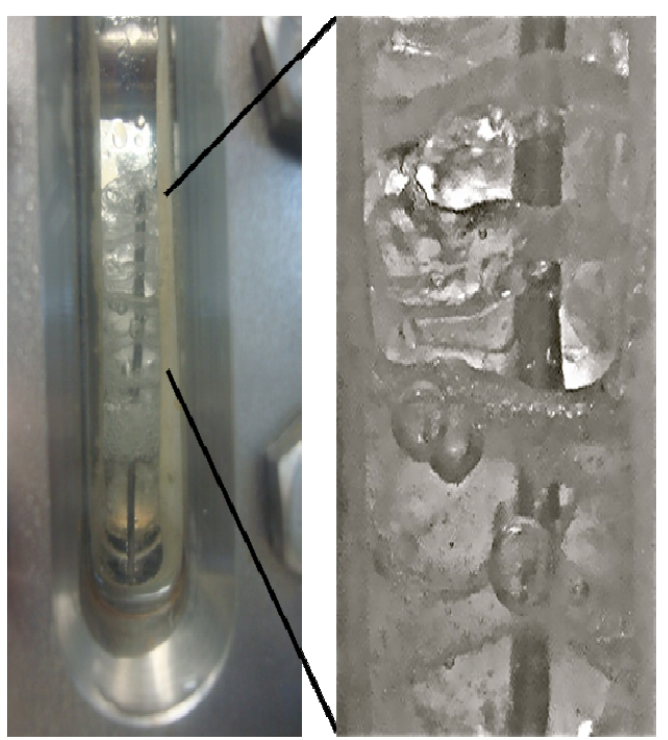

(c)

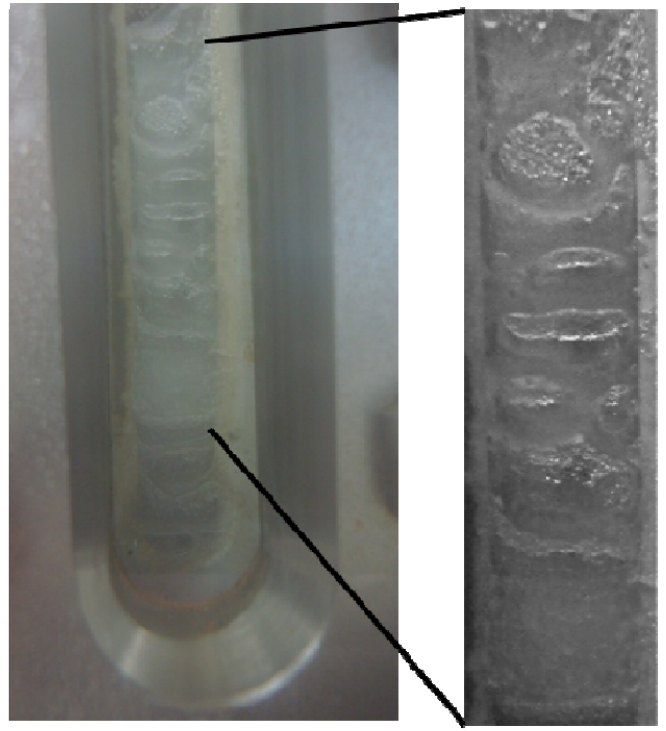

(b)

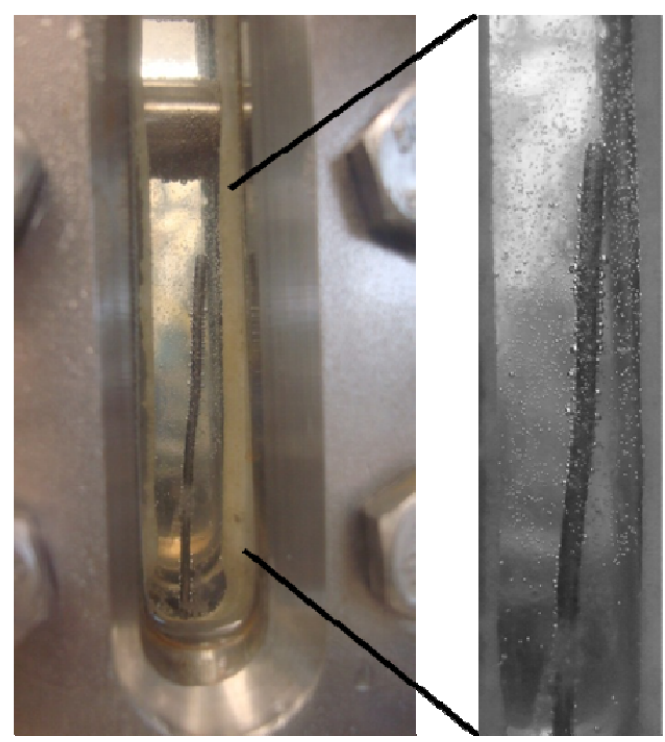

(d) 


\section{Conclusions}

A facile formation of $\mathrm{CO}_{2}$ hydrates was observed at high pressures and temperatures above freezing in a system in which water was in excess. The formed hydrates were found to accumulate in the aqueous phase at the bottom of the cell and not at the gas-liquid interface. The liquid interface was observed to be intact throughout the hydrate formation phenomenon which indicates that hydrates may have nucleated in the bulk solution or at the gas-liquid interface and then accumulated in the aqueous phase due to density difference.

The hydrate formation time was found to vary from $17 \mathrm{~h}$ to seven days. The conversion of about $32 \%$ of $\mathrm{CO}_{2}$ gas into hydrates was measured when SDS, a known hydrate former, was present. The overall $\mathrm{CO}_{2}$ hydrate yield could be increased with multiple gas charges though subsequent hydrate yield was low. This is explained by the decreased concentration of SDS in the solution as SDS tends to precipitate out after single use. A finding that $\mathrm{CH}_{4}-\mathrm{CO}_{2}$ gas mixtures that are $\mathrm{CH}_{4}$-rich yield a higher concentration of $\mathrm{CH}_{4}$ hydrates is contradictory to many previous findings, though these studies did not have gas mixtures made of predominantly $\mathrm{CH}_{4}$. This system needs further study. $\mathrm{CH}_{4}$ preference when forming gas hydrates from gas mixtures could be an important factor if $\mathrm{CO}_{2}$ sequestration in the $\mathrm{CH}_{4}$ free zone under the ocean floor is proposed. We are now investigating the use of computed tomography at the National Synchrotron Light Source (NSLS) to establish the morphology and stability of $\mathrm{CO}_{2}$ hydrates formed from $\mathrm{CH}_{4}-\mathrm{CO}_{2}$ gas mixtures.

\section{Acknowledgements}

This research was conducted at Brookhaven National Laboratory (BNL) under contract No. DE-AC02-98CH10886. KH was supported by the United States Department of Energy (US DOE) under the Office of Science-Summer Undergraduate Laboratory Internship (SULI) program, administered by BNL Office of Education Programs and the Department of Education-GAANN program for the Graduate Fellowship.

\section{References}

1. 2010 Carbon Sequestration Atlas of the United States and Canada, 3rd ed.; National Energy Technology Library: Pittsburgh, PA, USA, 2010. Available online: http://www.netl.doe.gov/ technologies/carbon_seq/refshelf/atlasIII/index.html (accessed on 26 June 2012).

2. Wang, Z.; Fu, Z.; Zhang, B.; Wang, G.; Rudolph, V.; Huo, L. Adsorption and desorption on coals for $\mathrm{CO}_{2}$ sequestration. Min. Sci. Technol. (China) 2009, 19, 8-13.

3. Ravagnani, A.T.F.S.G.; Ligero, E.L.; Suslick, S.B. $\mathrm{CO}_{2}$ sequestration through enhanced oil recovery in a mature oil field. J. Petrol Sci. Eng. 2009, 65, 129-138.

4. Rosenbauer, R.J.; Koksalan, T.; Palandri, J.L. Experimental investigation of $\mathrm{CO}_{2}$-brine-rock interactions at elevated temperature and pressure: Implications for $\mathrm{CO}_{2}$ sequestration in deep-saline aquifers. Fuel Process Technol. 2005, 86, 1581-1597.

5. Siriwardane, H.J.; Gondle, R.; Smith, D.H. Influence of shrinkage and swelling properties of coal on geological sequestration of carbon dioxide. In Proceedings of the 2006 SPE Annual Technical Conference and Exhibition, San Antonio, TX, USA, 24-27 September 2006. 
6. Goel, N. In situ methane hydrate dissociation with carbon dioxide sequestration: Current knowledge and issues. J. Petrol Sci. Eng. 2006, 51, 169-184.

7. Tohidi, B.; Yang, J.H.; Salehabadi, M.; Anderson, R.; Chapoy, A. $\mathrm{CO}_{2}$ hydrates could provide secondary safety factor in subsurface sequestration of $\mathrm{CO}_{2}$. Environ Sci Technol. 2010, 44, $1509-1514$.

8. Sloan, E.D.; Koh, C.A. Clathrate Hydrates of Natural Gases, 3rd ed.; CRC Press: Boca Raton, FL, USA, 2008.

9. Ohgaki, K.; Takano, K.; Moritoki, M. Exploitation of $\mathrm{CH}_{4}$ Hydrates under the Nankai Trough in Combination with $\mathrm{CO}_{2}$ Storage. J. Chem. Eng. Jpn. 1994, 20, 121-123.

10. Ota, M.; Morohashi, K.; Abe, Y.; Watanabe, M.; Smith, R.L.; Inomata, H. Replacement of $\mathrm{CH}_{4}$ in the hydrate by use of liquid $\mathrm{CO}_{2}$. Energy Convers. Manag. 2005, 46, 1680-1691.

11. Lee, H.; Seo, Y.; Seo, Y.T.; Moudrakovski, I.L.; Ripmeester, J.A. Recovering methane from solid methane hydrate with carbon dioxide. Angew. Chem. Int. Ed. 2003, 42, 5048-5051.

12. Sugaya, M.; Mori, Y.H. Behavior of clathrate hydrate formation at the boundary of liquid water and a fluorocarbon in liquid or vapor state. Chem. Eng. Sci. 1996, 51, 3505-3517.

13. Ripmeester, J.A.; Alavi, S. Molecular simulations of methane hydrate nucleation. ChemPhysChem 2010, 11, 978-980.

14. Lee, J.W.; Zhang, J.S.; Lee, S. Does SDS micellize under methane hydrate-forming conditions below the normal Krafft point? J. Colloid Interf. Sci. 2007, 315, 313-318.

15. Wu, Q.; Zhang, B. Memory effect on the pressure-temperature condition and induction time of gas hydrate nucleation. J. Nat. Gas Chem. 2010, 19, 446-451.

16. Seo, Y.T.; Lee, H.; Yoon, J.H. Hydrate phase equilibria of the carbon dioxide, methane, and water system. J. Chem. Eng. Data 2001, 46, 381-384.

17. Uchida, T.; Ikeda, I.Y.; Takeya, S.; Kamata, Y.; Ohmura, R.; Nagao, J.; Zatsepina, O.Y.; Buffett, B.A. Kinetics and stability of $\mathrm{CH}_{4}-\mathrm{CO}_{2}$ mixed gas hydrates during formation and long-term storage. ChemPhysChem 2005, 6, 646-654.

(C) 2012 by the authors; licensee MDPI, Basel, Switzerland. This article is an open access article distributed under the terms and conditions of the Creative Commons Attribution license (http://creativecommons.org/licenses/by/3.0/). 